12. Kholopova, V. (2000). «Path in the center». Composer Rodion Shchedrin. M.: Kompozitor [in Russian].

13. Tsilikin, D. (July 29, 2013). Lefty in the Mariinsky Theater: About what sings the flea. The newspaper Vedomosti, p.22 [in Russian].

14. Schtschedrin, R. (2013). Levsha (The Left-Hander) The Tale of the Crosseyed Left-Hander from Tula. Opera in 2 acts. Libretto by the composer after the story by Nikolai Leskov. Mainz: Schott Music [in Germany].

15. Schtschedrin, R. (2015). A Christmas Tale. Opera-extravaganza in 2 acts. Libretto by the composer after the fairy tale by Božena Nemtsova in the translation by Nikolai Leskow and Russian folk tales. Mainz: Schott Music [in Germany].

Стаття надійшла до редакції 15.06.2016

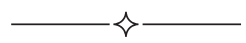

УДК 78.03

\author{
Наталья Вячеславовна Заяц, \\ соискатель Одесской национальной \\ музыкальной академии имени А. В. Неждановой
}

\title{
«НОЧИ В САДАХ ИСПАНИИ» МАНУЭЛЯ ДЕ ФАЛЬИ В КОНТЕКСТЕ ПРЕТВОРЕНИЯ ИСПАНСКОЙ НАЦИОНАЛЬНОЙ ИДЕИ
}

\begin{abstract}
Цель статьи. Статья посвящена анализу образно-смысловых и жанрово-стилевых аспектов цикла М. де Фальи «Ночи в садах Испании», рассматриваемого не только в русле поэтики творчества композитора, но и в контексте претворения в нем качеств испанской национальной идеи. Научная новизна. Испанская национальная идея реализуется как на уровне образно-смысловой архетипической специфики названного произведения, так и в воспроизведении в фортепианно-оркестровом фактурном варианте показательного для испанской музыкально-исторической традиции синтеза вокального, инструментального (гитарного) и танцевального начал. Выводы. "Ночи в садах Испании» демонстрируют контактность с традициями франиузского символизма, импрессионизма, предвосхищая открытия неофольклоризма ХХ $\mathrm{cm}$.
\end{abstract}

Ключевые слова: Испания, испанская национальная идея, испанская музыка, фламенко, фортепианное творчество М. де Фальи.

(с) Заяц Н. В., 2016 
Zayats Natalia, The Odessa National A. V. Nezhdanova Academy of Music, applicant of the department of theoretical and applied culturology

«Nights in the Gardens of Spain» by Manuel de Falla in the context of the implementation of the Spanish national idea

The purpose of the article analyzes the semantic and figurative genre and stylistic aspects of the cycle of M. De Falla's «Nights in the gardens of Spain», understood not simply in line with the poetics of the composer, but also in the context of the implementation of its qualities the spanish national idea. Scientific novelty. The latter is implemented at the level of figurative meaning of archetypal product of the specifics of the title, and in playing in a piano-orchestral version textural demonstration for the spanish musical tradition of the historical synthesis of vocal, instrumental (guitar) and the dance began. Conclusions. At the same time, «Nights in the gardens of Spain» exhibit rapport with the traditions of french symbolism, impressionism, anticipating opening neofolklorizm twentieth century.

Keywords: Spain, the spanish national idea, spanish music, flamenco, piano work of M. de Falla.

Заєць Наталія В'ячеславівна, здобувач Одеської національної музичної академії імені А. В. Нежданової

«Ночі в садах Іспанї̈ Мануеля де Фальї в контексті відтворення іспанської національної ідеї

Мета статmi. Стаття присвячена аналізу образно-смислових $i$ жанрово-стильових аспектів циклу М. де Фальї «Ночі в садах Іспанії», розглянутого не тільки в руслі поетики творчості композитора, але і в контексті втілення в ньому якостей іспанської національної ідеї. Наукова новизна. Іспанська національна ідея реалізуеться як на рівні образносмислової архетипічної специфіки названого твору, так і у відтворенні в фортепианно-оркестровому фактурному варіанті показового для іспанської музично-історичної традиції синтезу вокального, інструментального (гітарного) і танцювального начал. Висновки. «Ночі в садах Іспанї̈» демонструють контактність з традиціями франиузького символізму, імпресіонізму, передбачаючи відкриття неофольклоризму XX $\mathrm{cm}$.

Ключові слова: Іспанія, іспанська національна ідея, іспанська музика, фламенко, фортепіанна творчість М. де Фальи.

Актуальность. Испанский историк Хуан Лалагуна, рассматривая этапы исторического развития своей родины, выделяет характерное испанское выражение: «La geografia manda» - «За географией всегда последнее слово» [5]. Действительно, культура этой страны много столетий развивалась на пересечении западных и восточных влияний, что и определяет самобытность ее национальной идеи и разнообразных форм ее художественного претворения. От остальной Евро- 
пы ее отделяло своеобразие географического положения, повлекшее за собой и синтез влияний Запада и Востока, и разноголосицу провинций, резко отделенных друг от друга климатическими контрастами и языковыми диалектами. Не случайно слово «Испания» на протяжении многовековой истории страны чаще всего использовалось во множественном числе [9, 234].

Культура этой страны много столетий развивалась на пересечении западных и восточных влияний, что и определяет самобытность ее национальной идеи и разнообразных форм ее художественного претворения. Выделенные особенности в сочетании с парадоксами исторического и культурного развития привели к повышенному интересу художников и исследователей Европы к испанской культуре, в том числе и музыкальной.

Цель статьи. Статья посвящена анализу образно-смысловых и жанрово-стилевых аспектов цикла М. де Фальи «Ночи в садах Испании», рассматриваемого не только в русле поэтики творчества композитора, но и в контексте претворения в нем качеств испанской национальной идеи. Научная новизна. Испанская национальная идея реализуется как на уровне образно-смысловой архетипической специфики названного произведения, так и в воспроизведении в фортепианно-оркестровом фактурном варианте показательного для испанской музыкально-исторической традиции синтеза вокального, инструментального (гитарного) и танцевального начал.

Изложение основного материала. М. де Фалья, отличавшийся творческой одаренностью, широтой интересов, в своей многогранной деятельности сумел достаточно полно воплотить в рамках культуры рубежа XIX-XX ст. национальные и духовные идеи испанской музыкальной культуры, формировавшейся на базе взаимодействия различных этнических и религиозных традиций, обусловленных историко-географическим статусом Испании. Широкий спектр творческих задач по воплощению национальной идеи своей родины, которые ставил перед собой М. де Фалья, нашел запечатление и в жанровом разнообразии его наследия. Одно из существенных мест в нем занимает фортепианная музыка. Названная сфера творчества М. де Фальи, представленная «Ноктюрном» (1896), «Андалусской серенадой» (1900), «Фантастической сюитой» (1901), циклом «Четыре испанские пьесы для фортепиано» (1906-1909), Концертом для клавесина и инструментального ансамбля (1926), обработкой «Песни волжских бурлаков» (из русского музыкального фольклора) (1922) и, наконец, 
монументальной фортепианно-оркестровой композицией «Ночи в садах Испании» (1909-1916), пока не стала предметом фундаментальных исследований в отечественном музыкознании в ракурсе направленности ее содержания на специфику запечатления испанской национальной идеи, что обуславливает актуальность темы представленной статьи. Ее цель ориентирована на выявление жанрово-стилевой и образно-смысловой специфики цикла «Ночи в садах Испании» и особенностей запечатления в нем испанской национальной идеи.

По мысли Г. Гачева, «описать национальное - это выявить уникальное» $[11,3]$. Любая нация и ее культура существуют в течение длительного времени, и закономерно, что на протяжении столь долгого срока ее традиции не могут не меняться. Происходят различные переломы, смены ориентиров, все то, благодаря чему можно говорить о развитии, эволюции или революции национальной культуры. Постоянные и устойчивые признаки национальной культуры сложно вычленить, и существуют многочисленные подходы к решению этой проблемы. Одним из таковых можно считать феномен «национальной идеи». Своеобразным итогом-обобщением исследовательских изысканий в данной области можно считать определение Н. Головатого, представляющего важнейшие составляющие данного понятия, в числе которых выделены «політичний проект майбутнього нації, імператив iї свідомості й чину, смисложиттєвий чинник національного розвою; певний комплекс вірувань, національного світобачення і розуміння, своєрідний духовно-інтелектуальний потенціал нації, людини - державотворця і співгромадянина; система ціннісних орієнтацій, що полягає в урахуванні інтересів всіх верств суспільства, усіх народів; форма державного самоусвідомлення народу, показник того, як народ розуміє себе, своє місце і роль у світі» $[2,388]$.

Обобщение сведений по истории Испании различных эпох и ее культурно-исторической традиции позволяет выделить ряд составляющих ее национальной идеи. С одной стороны, очевидно ярко выраженное стремление к сохранению национальной идентичности на самых разнообразных уровнях, несмотря на внутригосударственную многонациональность, обусловленную историко-географическими факторами существования Испании. Сказанное нашло отражение и в ее культурных артефактах, и в Реконкисте - священной войне испанцев за родину, нацию, христианскую веру, и в борьбе нации за «чистоту» крови; позднее, в эпоху Нового времени - в создании идеализированного образа своей родины, заключавшегося в своеобраз- 
ном противостоянии так называемых «розовой» и «черной» легенд об Испании.

С другой стороны, показательна исторически закодированная открытость испанской нации и культуры к контактности с иными народами, что в особенности характерно для Андалузии. Испания по условиям своего исторического развития - своеобразный «мост» между Европой и мусульманским Востоком, что, отметим, нашло запечатление и в цикле М. де Фальи «Ночи в садах Испании». Одновременно на формирование культуры Испании, в том числе и духовнорелигиозной, существенное влияние оказала не только арабская, но и греко-византийская, а также и цыганская культуры.

Сказанное, по мнению исследователя А. Романовой, определяет «диалектику испанской культуры», заключенную «в глубоком влиянии Востока» и одновременно в «суровом непреклонном преодолении этого влияния» $[10,53]$. Диалектическое взаимодействие «охранительной» и «космополитической» тенденций испанской нации определяет принадлежность страны к так называемому типу «пограничных культур» [1].

Для Испании показательна значимость христианства, эволюционировавшего от греко-византийства, усвоенного в рамках мозарабской традиции, вплоть до католицизма. Утверждение и защита католической веры в сочетании с устоями монархии как важнейший фактор духовного сплочения испанской нации составляет один из существенных моментов испанской национальной идеи $[9,275]$.

Еще одним существенным ее качеством можно считать особого рода эмоционально-психологический настрой испанской ментальности, что в свое время дало право Сальвадору Мадариаге определить испанцев как «людей страсти» [7], воспринимающих мир сквозь призму оппозиционных, амбивалентных понятий, порождающих культуру «срыва», культуру «на грани», «поданную» под маской вечного праздника. Данное свойство существенно дополняется отвагой, мужеством и особой значимостью чувства собственного достоинства, выступающих в тесной взаимосвязи с обозначенными выше качествами испанской национальной идеи.

Культура, в том числе и музыкальная, составляет важнейший фундамент формирования и развития национальной идеи. В музыкальноисторической традиции символическим носителем национальной идеи всегда выступала как фольклорная, так и, прежде всего, гимническая традиция в ее духовно-религиозном и в светском вариантах, а 
также жанрово-стилистически близкие к ней. Применительно к проблематике данной статьи в подобном качестве можно рассматривать и испанскую танцевальную культуру, и искусство фламенко, канте хондо, и испанскую обрядовую культово-религиозную традицию. Ко всем названным артефактам испанской культуры проявляли огромный интерес не только непосредственно в Испании, но и далеко за ее пределами, о чем свидетельствует творчество М. де Фальи, его предшественников и современников, а также произведения французских и русских композиторов XIX века, для которых Испания стала одним из наиболее ярких проявлений национального в музыке и в культуре в целом.

М. де Фалья - выдающийся испанский композитор первой половины XX ст. - в своем творчестве активно развивал эстетические принципы и заветы Ф. Педреля, известного идейного вдохновителя и организатора движения за возрождение испанской национальной музыкальной традиции, ставшей в свою очередь составной частью феномена Ренасимьенто, охватившего все стороны культурной жизни Испании обозначенного периода. Ярко выраженное национальное качество его музыки органично сочеталось с широкой осведомленностью в жанрово-стилевых процессах европейской культуры в целом, тесными контактами с К. Дебюсси, М. Равелем, П. Дюка, русскими музыкантами, обусловив тем самым синтез в его творчестве собственно испанского и общеевропейского начал. По мнению И. А. Кряжевой, «благодаря этому синтезу его [М. де Фальи] музыка представила совершенно новый образ национального, который имел мало общего с общепринятыми в то время стереотипами и клише. Растиражированный в европейском искусстве второй половины XIX века образ Испании, отражавший, в основном, внешнюю экзотику и от этого поверхностный, к зрелым сочинениям Фальи неприложим. В сфере его внимания - нечто исконное, сущностное, иногда пугающее своей вневременной глубиной и масштабностью. Искусство Фальи уходит от клише и приходит к архетипам. И в этом он проявляет себя как художник XX века, сопоставимый с такими композиторами, как И. Ф. Стравинский, Б. Барток, П. Хиндемит» [4, 6-7].

Обозначенный творческий подход М. де Фальи в реализации архетипического национального качества, обобщенного в базовых позициях испанской национальной идеи, наиболее полно проявился в его фортепианно-оркестровом цикле «Ночи в садах Испании», законченном в 1916 г. 
Учитывая историю возникновения данного произведения, создававшегося на протяжении семи лет (1909-1916), необходимо отметить, что оно было рождено на пересечении многих национальных традиций, что соответствует одному из базовых качеств испанской национальной идеи - открытости иным культурам, способности вступать с ними в активный контакт-взаимодействие (см. выше). С одной стороны, исследователи творчества М. де Фальи указывают на связь данного произведения с французской и русской музыкально-историческими традициями, вызывавшими у него живейший интерес. По свидетельству И. А. Кряжевой, ««Испанская рапсодия» Равеля, «Море» и «Иберия» Дебюсси - музыкальный контекст, который направляет и формирует устремления испанского композитора в этот период. Добавим сюда и мощное влияние русской школы, в первую очередь симфонизма Римского-Корсакова, Бородина, а чуть позже Стравинского» [4, 126].

Очевидная доминирующая роль и влияние музыкального языка К. Дебюсси на творчество М. де Фальи в свое время подчеркивал и сам композитор в своей статье «Клод Дебюсси и Испания», отмечая, что великий французский автор «в известной мере дополнил открытия маэстро Фелипе Педреля в сфере ладовых богатств и возможностей, заключенных в нашей музыке», и что «его гармоническое письмо подсказывает много интересных идей испанским композиторам» [цит. по: 8, 75].

Иным связующим звеном между партитурой «Ночей в садах Испании» и стилевыми исканиями эпохи К. Дебюсси можно считать также и авторское определение рассматриваемого сочинения «Симфонические впечатления для фортепиано и оркестра», вызывающие явные ассоциации с мироощущением французского импрессионизма, для эстетики которого слово «впечатление» было одним из определяющих и смыслообразующих.

Подобного рода концепция во многом определяла и жанровую «многовекторность» данного сочинения. Изначально задумывавшиеся как «Ноктюрны» (еще один аналог с К. Дебюсси) для фортепиано, «Ночи в садах Испании» в конечном итоге трансформировались в «Симфонические картины» с участием солирующего фортепиано. Одновременно, данная трехчастная циклическая композиция вызывает также аналогии и с романтическим фортепианным концертом, который, вместе с тем, весьма далек от его виртуозно-бравурных аналогов, известных в музыкально-исполнительской практике XIX ст. 
С романтической стилистикой данный цикл роднит и символика «ночи», заявленная в программном определении.

Программный замысел «Ночей в садах Испании», ладово-интонационный и жанровый колорит этого произведения свидетельствуют о его достаточно ярко выраженном национальном испанском качестве, очевидном в программных подзаголовках всех трех частей произведения: «В Хенералифе», «Отдаленный танец», «В садах Сьерры-Кордовы». При этом первая и третья части демонстрируют столь показательный для испанской инструментальной музыки (в том числе и фортепианной) рубежа XIX-XX ст. географический «крен», ориентированный не столько на историко-литературный тип образности, сколько на запечатление неповторимого колорита различных регионов Испании и их культуры. Сказанное демонстрируют также и циклы И. Альбениса («Иберия», две «Испанские сюиты», «Воспоминания о путешествии»), Э. Гранадоса («12 испанских танцев») и др.

Отметим также, что географическая «ориентация» программных определений анализируемого сочинения М. де Фальи выявляет еще одно показательное для испанской культурной и ментальной традиции качество, обусловленное спецификой ее истории - взаимодействие собственно испанского и арабо-мусульманского начал. Хенералифе, упоминающееся в программном определении 1 ч., - это бывшая загородная резиденция эмиров династии Насридов, правивших Гранадой в XIII-XIV вв. Она находилась в непосредственной близости от Альгамбры и Альбайсина, являя собой шедевр садоводческого искусства, воссоздающего образ мусульманского рая. По мнению Т. П. Каптеревой, исследовавшей семантику и символику садов Испании, «сады Хенералифе, как и дворцы Альгамбры, отличаются подчеркнутой картинностью... Характерное для культуры ислама гармоничное, созерцательное бесконфликтное начало придает саду впечатление разлитой вокруг благоухающей тишины...» [3].

К аналогичному кругу образов обращена и программа финальной части «Ночей в садах Испании» М. де Фальи, ориентированная на сады Сьерры-Кордовы - некогда арабской столицы Иберийского полуострова. Дополняет названный историко-географический образ, по мнению И. Мартынова, также и жанровая ориентация финала на самбру, исторически связующую испанскую и арабскую традиции. «Самбра - собрания, на которых читались отрывки из «Тысячи и одной ночи» в сопровождении музыки и пения. Позднее самбра превратилась в ночной праздник с участием цыганских музыкантов» 
$[8,79]$. В «Кратком словаре танцев» «Самбра (цамбра) (исп. Zambra «шумное пиршество морисков (мавров)») - мавританский танец живого характера (в прошлом); в настоящее время танец испанских цыганок» [12], демонстрирующий вековую «сращенность» восточного и собственно испанского начал.

Апеллирование композитора к всемирно известным «садам Испании» обусловлено не только их прекрасной природой и высокохудожественной организацией окружающего ландшафта, но и духовносмысловым подтекстом понятия «сад», сближающим европейскую и восточную традиции, что получило наиболее полное запечатление именно в испанской культуре. В данном случае сад, по мнению Д. С. Лихачева, - «это попытка создания идеального мира взаимоотношений человека с природой. Поэтому сад представляется как в христианском мире, так и в мусульманском раем на земле, Эдемом... Сад всегда выражает некоторую философию, эстетические представления о мире, отношение человека к природе; это микромир в его идеальном выражении» [6, 11].

Подобный подход в запечатлении «Садов Испании» показателен и для известного испанского художника Сантьяго Русиньоля - современника М. де Фальи. Известно, что вышедший в начале XX ст. одноименный живописный альбом художника, а также довольно тесные личные и творческие контакты с ним самого композитора оказали непосредственное воздействие на создание рассматриваемого цикла. Многие исследователи «отмечают тонкую связь живописи Русиньоля и музыки Фальи, то своеобразное соединение звуковых и визуальных образов, когда музыка, по мысли автора, не имеет описательной цели, а скорее ставит себе задачу «вызвать воспоминания мест, ощущений, чувств». Такая скрытая зашифрованная взаимосвязь музыки и пейзажа интересна своей недосказанностью и многозначностью, когда возникают пересечения не только с импрессионизмом, но и с символизмом» $[4,128]$. Отметим, что подобного рода пересеченность живописного и музыкально-композиторского методов в запечатлении образа Испании и испанской национальной идеи показательна и для творчества Э. Гранадоса - автора известного фортепианного цикла «Гойески».

Выводы. Испанское национальное качество «Ночей в садах Испании» М. де Фальи проявляется и в музыкальном языке, демонстрирующем новый подход автора к запечатлению фольклорной традиции своей родины. Если предшествующие сочинения, в том числе и 
опера «Короткая жизнь» изобиловали цитатами конкретных фольклорных тем, а также воспроизведением соответствующей исполнительской манеры, то в данном случае автор избегает прямых цитат, идя по пути, скорее, обобщенного воспроизведения интонационного языка фламенко и характерных для него способов звукоизвлечения. «Весьма разнообразно Фалья воссоздает манеру игры на гитаре, в частности, такие приемы как тремоло, расгеадо, причем это касается не только фортепиано, но и оркестра (например, четырех-пятизвучные пассажи с акцентом на первую долю в оркестровой фактуре в быстром темпе, «В Хенералифе» ц. 5). Неоднократно он реконструирует характерную для фламенко диалогическую манеру, когда фортепиано уподобляется солисту, а энергичные краткие фразы оркестра тутти гитарному аккомпанементу в манере расгеадо» $[4,130]$. Последний прием являет собой не только эффектно звучащий «ударный» аккорд, но и ассоциируется у испанских исполнителей с мгновенно раскрывающимся испанским веером.

Одновременно обозначенные исполнительские приемы сочетаются в «Ночах в садах Испании» с характерными приметами андалузского фольклора, в числе которых ладовая переменность, очевидно воспринимаемые на слух элементы «доминантового лада», орнаментика, мелизматика, характерные кадансовые обороты. Показательно также использование композитором такого характерного фактурного приема, как октавное дублирование в партии фортепиано мелодической линии при яркой динамике, вызывающее ассоциации с виртуозно-эмоциональными вокализациями кантаора. Тематизм рассматриваемого сочинения в большей степени тяготеет не к протяженным мелодическим линиям, а к попевочности и вариантной повторности как базовому принципу ее развития. В этом плане творческий метод М. де Фальи сближается с традициями неофольклоризма как одного из базовых направлений европейской музыки первой половины $\mathrm{XX}$ ст.

Ярко выраженное национальное качество музыкального языка «Ночей в садах Испании» сочетается с поисками новых оркестровотембральных средств выражения, в том числе сопряженных и с вниманием к пространственным и темброво-динамическим качествам звука. Сказанное относится ко второй части цикла, имеющей, как указывалось ранее, подзаголовок «Отдаленный танец». Как отмечает И. Мартынов, «по этому поводу А. Готье ставит вопрос: о какой отдаленности идет речь - в пространстве или во времени, усматривая 
в начальных тактах отзвуки старинного менуэта» $[8,78]$. Размышляя об «особой мистической атмосфере» данной части, И. А. Кряжева приводит любопытный комментарий самого композитора «по поводу специфической акустической организации «Отдаленного танца». Однажды, находясь у себя дома на улице Антекеруэла, которая располагается достаточно близко, но все же на некотором отдалении от Альгамбры, Фалья сказал следующее: «Это так, как если бы там в Мартирес [сад и дворец возле Альгамбры] звучал танец, а мы бы его слушали отсюда»» $[4,138]$. Аналогичного рода поиски звукового запечатления эффекта приближения и удаления также показательны и для «Ноктюрнов» К. Дебюсси (2-я часть «Празднества»).

Отметим также своеобразный подход М. де Фальи и к партии солирующего фортепиано, которая в данном случае лишена столь показательной для романтического пианизма виртуозности. В большинстве случаев фортепиано выступает скорее как один из участников оркестра, наделенный особым тембровым качеством и способностью обобщенного воспроизведения и гитарного звучания, и вокальной экспрессии кантаора, и метро-ритмического тонуса испанской танцевальной традиции. В данном случае, на наш взгляд, сказывается и столь показательное для испанской культуры в целом тяготение к синтезу-симбиозу певческого, инструментально-исполнительского и танцевального начал в передаче национального качества, глубинных аспектов испанской национальной идеи и полноты ее художественного запечатления.

Таким образом, жанрово-стилевые и образно-смысловые аспекты партитуры «Ночей в садах Испании» свидетельствуют не только о рождении испанского симфонизма, синтезирующего национальное качество с достижениями европейской музыкально-исторической традиции, но и о художественно-обобщенном воплощении в данном сочинении качеств испанской национальной идеи, апеллирующей к ее духовным архетипам, в том числе и к саду как олицетворению гармонии, рая, земного Эдема. Сады Альгамбры, семантика которых во многом определила программный замысел и М. де Фальи, и живописных работ Сантьяго Русиньоля, - «это особый мир, в котором в поразительном единстве существуют природа, искусство и история, благодаря чему столь символично и многозначно это пространство, пробуждающее творческую фантазию у всех, кто побывал здесь» $[4,128]$. 


\section{СПИСОК ЛИТЕРАТУРЫ}

1. Антонова Е. Россия и Испания как пример пограничных культур между Востоком и Западом // Научный вестник МГГУ ГА. 2005. № 95 (13). С. 164166.

2. Головатий М. Національна ідея // Етнократологічний словник : енцикл.-довід. слов. / [За ред. О. В. Антонюка, М. Ф. Головатого та Г. В. Щокіна]. К. : МАУП, 2007. С. 388-389.

3. Каптерева Т. Сады Испании. М.: Прогресс-Традиция, 2007. URL: iknigi. net/avtor-tatyana-kaptereva/49360-sady-ispanii-tatyana-kaptereva/read/page-1. html

4. Кряжева И. Мануэль де Фалья: время, жизнь, творчество : монография. М.: Научно-издательский центр «Московская консерватория», 2013. $328 \mathrm{c}$.

5. Лалагуна Х. Испания. История страны / Пер. с англ. Е. Гобитбаевой, М. Бамтакова. М.: Эксмо: СПб.: Мидгард, 2009. 352 с.

6. Лихачев Д. Поэзия садов. К семантике садово-парковых стилей. Сад как текст. М.: «Согласие», ОАО «Типография «Новости»», 1998. 356 с.

7. Мадариага де С. Англичане, французы, испанцы / Пер. с английского Говорунова А. В. СПб.: Наука, 2003. 239 с.

8. Мартынов И. Мануэль де Фалья. Жизнь и творчество. М.: Советский композитор, 1986. $192 \mathrm{c.}$

9. Национальная идея в Западной Европе в Новое время. Очерки истории / Отв. редактор В. С. Бондарчук. М.: ИКД «Зерцало-М»; Издательский дом «Вече», 2005. $469 \mathrm{c}$.

10. Романова А. Проблема исполнительской организации художественного времени в произведениях фольклорно-вариантного склада (на примере цикла И. Альбениса «Иберия») // Южно-российский музыкальный альманах. 2010. № 1. С. 52-56.

11. Фогель М. Роль национальной идеи в современном политическом развитии России и Германии : автореф. дис. ... канд. политических наук : 23.00 .01 - «Теория политики, история и методология политической науки». М.: МГУ им. М. В. Ломоносова, 2004. 29 с.

12. Шетэля В. Краткий словарь танцев. М.: Флинта, Наука, 2011. URL: iknigi.net/avtor-viktor-shetelya/47018-kratkiy-slovar-tancev-viktor-shetelya. html

\section{REFERENCES}

1. Antonova, E. (2005). Rossiya i Ispaniya kak primer pogranichnyih kultur mezhdu Vostokom i Zapadom // Nauchnyiy vestnik MGGU GA. 2005. \# 95 (13) [in Russian].

2. Holovatyy, M. (2007). Natsional'na ideya // Etnokratolohichnyy slovnyk : entsykl.-dovid. slov. / [Za red. O. V. Antonyuka, M. F. Holovatoho ta H. V. Shchokina]. K. : MAUP [in Ukrainian]. 
3. Kaptereva, T. (2007). Sadyi Ispanii. M.: Progress-Traditsiya. URL: iknigi.net/ avtor-tatyana-kaptereva/49360-sady-ispanii-tatyana-kaptereva/read/page-1.html [in Russian].

4. Kryazheva, I. (2013). Manuel de Falya: vremya, zhizn, tvorchestvo : monografiya. M.: Nauchno-izdatelskiy tsentr «Moskovskaya konservatoriya» [in Russian].

5. Lalaguna, H. Ispaniya. Istoriya stranyi (2009) / Per. s angl. E. Gobitbaevoy, M. Bamtakova. M.: Eksmo: SPb.: Midgard [in Russian].

6. Lihachev, D. (1998). Poeziya sadov. K semantike sadovo-parkovyih stiley. Sad kak tekst. M.: «Soglasie», OAO «Tipografiya «Novosti» [in Russian].

7. Madariaga de S. (2003). Anglichane, frantsuzyi, ispantsyi / Per. s angliyskogo Govorunova A. V. SPb.: Nauka [in Russian].

8. Martyinov, I. (1986). Manuel de Falya. Zhizn i tvorchestvo. M.: Sovetskiy kompozitor [in Russian].

9. Natsionalnaya ideya $\mathrm{v}$ Zapadnoy Evrope $\mathrm{v}$ Novoe vremya. Ocherki istorii (2005) / Otv. redaktor V. S. Bondarchuk. M.: IKD «Zertsalo-M»; Izdatelskiy dom «Veche» [in Russian].

10. Romanova, A. (2010). Problema ispolnitelskoy organizatsii hudozhestvennogo vremeni $\mathrm{v}$ proizvedeniyah folklorno-variantnogo sklada (na primere tsikla I. Albenisa «Iberiya) // Yuzhno-rossiyskiy muzyikalnyiy almanah. \# 1. [in Russian].

11. Fogel, M. (2004). Rol natsionalnoy idei v sovremennom politicheskom razvitii Rossii i Germanii : Avtoref. diss. ... kand. politicheskih nauk : 23.00.01 - «Teoriya politiki, istoriya i metodologiya politicheskoy nauki». M.: MGU im. M. V. Lomonosova [in Russian].

12. Shetelya, V. (2011). Kratkiy slovar tantsev. M.: Flinta, Nauka. URL: iknigi.net/avtor-viktor-shetelya/47018-kratkiy-slovar-tancev-viktor-shetelya.html [in Russian].

Стаття надійщла до редакції 08.06.2016

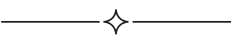

